\title{
The Identification of Archaeological Remains for Local Identity Contruction in Southeast Celebes
}

\author{
Sandy Suseno ${ }^{1}$, Syahrun ${ }^{2}$, Abdul Alim ${ }^{3}$, Salniwati ${ }^{4}$, Siti Kasmiati ${ }^{5}$ \\ \{sandy.suseno@uho.ac.id ${ }^{1}$, syahrun_antro@yahoo.com ${ }^{2}$, abdul.alim290172@gmail.com ${ }^{3}$, \\ salniwatis@gmail.com ${ }^{4}$, sittikasmiati@gmail.com ${ }^{5}$ \} \\ ${ }^{12345}$ Faculty of Cultural Sciences, Universitas Halu Oleo Kendari, Sulawesi Utara, Indonesia
}

\begin{abstract}
For archaeologists, Celebes has been known as a cultural melting point in the past. Therefore, archeological remains were found and scattered almost throughout in the celebes region, including Southeast celebes. When viewed from its landscape, Southeast Celebes consists of karst area arrangement that has the potential to be used and lived by the society in the past. The methods of this research is identification and observation of the spot with archaeological remains. From the identification and observation thats found the similarity characterisic archaeological remain from different site. In this paper, the identification of archeological remains in Southeast Celebes will be presented to show the past civilization in this region. At the present that area consists of the administrative regions of Konawe, Kolaka, Muna and Buton. The archeological remains in thats area can be the one of the bases of reference to assembling local identities in Southeast Celebes. Because of that, this article will examine the role of archaelogical remains to reconstruct the past to assemble the local identity of the community for the present and the future.
\end{abstract}

Keywords-Archaeological remains, local identities,southeast celebes

\section{Introduction}

Southeast celebes has a variety of ethnic cultures. Cultural diversity on its journey became the identity of each ethnic and made the multiculturalsm in Southeast Celebes. The multiculturalism cant inseparable from the need of recognition of the diversity in the present. Therefore, multiculturalism as an ideology that same like a tool or vehicle to increase appreciation for the equality of the human beings and their humanity. The operational of multiculturalism manifested through existing social institutions that found in the present. It can be said that multiculturalism is a concept that legitimizes cultural diversity which is then translated into various cultural policies by emphasizing acceptance of religious reality, plurality, and multiculturalism in people's lives [1]. Because of that, the local culture in ethnic or cultural groups can be a social formation to construction the spaces for diversity of identities and at the same time being the bridge to connects thats spaces for integration [2]. Cultural diversity in Southeast Celebes which originates from local culture is a real picture of the local identities of various ethnic groups in Southeast Celebes. The multiculturalsm of ethnicity in the 
Southeast Celebes in the present, it is also necessary to criticize with local culture in the past. Discources for the cultural disclosure in the past that needs to be done so the multiculturalism that exists at the present does not become a gap between ethnic groups. The archeological remains at prehistoric sites in Southeast Celebes becomes the sign to know that the cultural diversity today is a continuation of cultural evolution. The existence of these sites is also supported by the existence of landscapes in the Southeast Celebes thats consisting the karst . In the past, the karst became the area where humans lived. Therefore, in the Southeast Celebes we can found sites are spread of Southeast Celebes Region, namely, Konawe, Kolaka, Muna Island, and Buton. However, the archeological remains is not yet seen as a basic reference to construct the local identities in Southeast Sulawesi

\section{Methods}

The method is carried out by describing the comparison of archeological remains found in various regions in Southeast Celebes consisting of North Konawe, South Konawe, Konawe Islands, Kolaka, and Muna. These sites consist of Kuya Cave, Tengkorak I Cave, Tengkorak II Cave, Tengkorak III Cave, Pondoa Cave, Solo Oti Cave thats located in North Konawe. Kumapo Leleka Cave in South Konawe. And then, Watumea Cave and the Mala-Mala site located in Kolaka, Liang Kabori Area in Muna, Lia Gusi Cave in Central Buton, and the Dompo-Dompo Cave which is located in Konawe Islands. All the site has observed to find the various artefact, ecofact and feature. After that, the data must be clasified to find the characteristic. The characteristic of each other must be compare with data from another site. The archeological remains in the form of artifacts, ecofacts and features. To find a the reference for contruct the local identities today that based on archeological remains, the archeological remains will be compared with each other. It aims to obtain uniformity of attributes in archeological remains. In addition, the archeological remains that were used as a comparison are relics in prehistoric times. Because at this time it can be considered the origin of the civilization and cultural diversity today.

\section{Results dan Discussion}

\subsection{Pottery of Settlement Sites in Southeast Celebes}

Ceramics is the proof of human civilization in the past. In archeological studies, ceramics are divided into 3 types, namely earthware, stoneware, and porcelain. The three types are actually represent of the level of technological mastery of the culture society. That is, if on a the site found 3 types, we can be assumed that have continous process of settlement. All the types of ceramics are also found at various sites in Southeast. This proves that settlement sites in Southeast Celebes are residential sites that are used sustainably. The findings of pottery at prehistoric sites in Southeast Celebes are very varied and spread throughout the Southeast Celebes region. These sites are the Kuya Cave, Tengkorak I Cave, Tengkorak II Cave, Tengkorak III Cave, Watumea Cave, Mala-Mala Site, Solo Oti Cave, Dompo-Dompo Cave, Kumapo Leleka Cave, Lia Gusi Cave. The variations of pottery decoration consist of lines, points, circles, triangles, and the combinations all of that [3]-[6]. 


\subsection{Ceramics at Settlement Sites in Southeast Sulawesi}

The development of technological in the prehistoric in the Celebes civilization does not recognize the ability to make ceramics (in archeology known as porcelain). Therefore, it can be assumed that ceramics at the prehistoric cave in Southeast Celebes are the result of diplomatic relationship between two or more different cultures. Prehistoric sites in Southeast celebes that found the ceramics are Tengkorak I Cave, and Tengkorak II Cave in North Konawe, the Watumea Cave and the Mala-Mala Site in Kolaka, and Lia Gusi Cave in Central Buton. These ceramics were indicated to be blue and white which were very popular after the 17 th century.

\subsection{Rock Arts in Southeast Celebes}

The rock arts in Pondoa Cave consists of depicting a hand stencil in a naturalist style that uses charcoal for its depiction. Based on the iconography of the images contained in the rock arts in the Pondoa Cave longest originated from the late plestocene. In addition, the picture of the Pondoa Cave rock art can be said to be part of "the austronesian drawing tradition". The variation of rock arts in Pondo Cave consist of geometric, anthropomorphic, zoomorphic, boat and scene images. When viewed from the color of use, the picture that uses black is younger than the picture in red. Rock arts are also found in caves in the Liang Kabori area, Muna. The pictures consist of geometrical, anthropomorphic, zoomorphic, and scene. Based on relative comparisons with rock arts sites in Southeast Asia. It is known that rock images with the type of scene associated with earthenware have existed since the neolithic era, 3500 years ago. In Indonesia, in particular the depictions of bird fighting scenes have existed and have ritual and symbolic functions. This also applies to rock arts in the Kabori area, Muna. One very interesting figure is the portrayal of a boat in the Liang Kabori karst. The boat figures are found in Pominsa Cave, Metanduno Cave, Lakan Taghu Cave, and Kabori Cave [7].

\subsection{Burial Rites in Prehistoric Caves in Southeast Celebes}

Some of the prehistoric caves that have archeological remains also have an association with the human bones. Based on the location and position of the bones it is known that the human bones is a parts of secondary burials. The sites that give a clear indication of secondary burials are thats is Kuya Cave, Tengkorak II Cave, Tengkorak III Cave located in North Konawe, and Kumapo Leleka Cave is in South Konawe. While other sites give an indication of burial cave sites, namely Solo Oti Cave in North Konawe, and Lia Gusi Cave, located in the Central Buton.

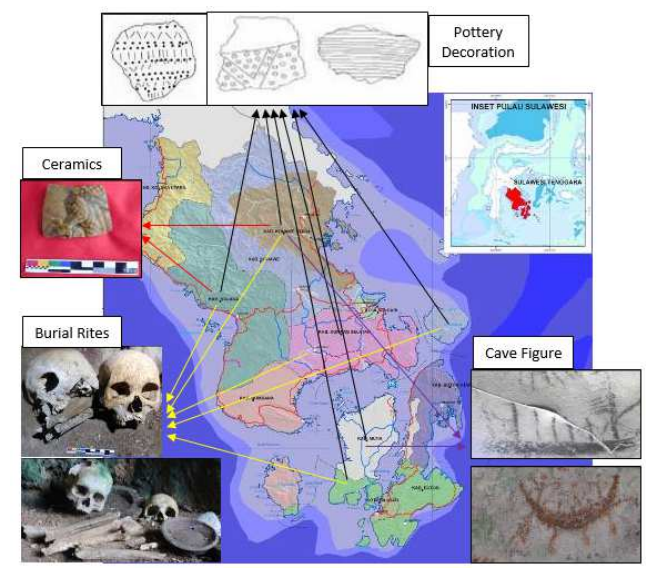

Fig. 1. Illustrated the Distribution and Variety of Archaeological Remains In South East Celebes 


\subsection{Archaeological remains for construction of local identity in Southeast Celebes}

Talking about the local identity of an ethnic seems to be traced from the traditions of the ethnic group [8]. Therefore, the identity that is formed now should be rooted in ethnic cultural life in Southeast Celebes in the past. One review that needs to be considered to investigate the roots of local identity is the archeological remains. Especially the past culture on Celebes Island has long attracted the attention of archaeologists to explore. This is because this region is cultural crossing point in the past. This is supported by the landscape on Celebes Island that form by the karst, an thats area has always been used by humans as a place to lived. A place of residence or settlement for archaeologists is defined as a site or location consisting of settlements and social interactions that occur within it. Therefore, settlement is not only understood as a feature of the past, but also the cultural context integrated with the site. The complexity that exists at past settlement sites is a record of past cultural information that needs to be explored by today's society [9].

Based on archeological remains, that is known that multiculturalism formed in ethnicity today is rooted in the universality cultures in past. It can be seen from the similarity of pottery decoration. In addition, the similarities in the burial rites in the past various sites in Southeast Celebes give an indication that the burial rites in the cave also apply universally to ethnic groups in Southeast Celebes. The past socio-economic life is illustrated by the presence of ceramics at various sites in Southeast Celebes. This indicates that the ethnic groups in Southeast Celebes have known diplomatic relations with other communities and also explained the existence of social strata in the past. Depictions of past livelihoods can be seen from rock arts in prehistoric caves. The profile of a strong maritime tradition is reflected through the manifestations of material and non-material culture in the region [10]. The material aspect is depicted on the rock arts in the shape of a boat thats found in rock art at the Pondoa Cave and Liang Kabori area. This explains that the roots of cultural ethnic in Southeast Celebes cannot be separated from the maritime.

\section{Conclusion}

Archaeological remains should be the basis for constructing the local identity of cultural community. It aims to understand the multiculturalism that exists today is the result of the cultural evolution of the past culture universal. Furthermore, archeological remains become evidence that explains the process of cultural evolution that took place the multicultural ethnicity that we encounter today. This happened in Southeast Celebes, based on various archeological remains multicultural in southeast Celebes was formed from universal cultural roots with maritime life oriented. So, from this research to contructing the local identity must based from archaeological remains.

\section{References}

[1] A. Azra, "Identitas dan Krisis Budaya: Membangun Multikulturalisme Indonesia," www.lpmpbanten.net, 2007. .

[2] D. Sparringa, Multikulturalisme dalam Multiperspektif di Indonesia. Surabaya: Forum Rektor Simpul Jawa Timur, 2003. 
[3] Y. A. Sendana and A. R. Sulaema, "Tembikar Pada Gua Kuya di Desa Pondoa Kecamatan Konawe Utara Provinsi Sulawesi Tenggara (Kajian Bentuk dan Ragam Hias),” Sangia J. Penelit. Arkeol., vol. 1, no. 1, pp. 30-43, 2017.

[4] A. A. Ratnasari, "Fungsi Gua Solo Oti Di Desa Taipa Kecamatan Lembo Kabupaten Konawe Utara," Sangia J. Penelit. Arkeol., vol. 3, no. 1, pp. 57-77, 2019.

[5] M. Maskuri, "Sebaran Gua Penguburan Di Kabupaten Konawe Kepulauan Provinsi Sulawesi Tenggara," Sangia J. Penelit. Arkeol., vol. 1, no. 2, pp. 46-61, 2017.

[6] F. Pradana and S. Kasmiati, "Identifikasi Gua Kumapo Di Desa Leleka Kecamatan Wolasi Kabupaten Kabupaten Konawe Selatan," Sangia J. Penelit. Arkeol., vol. 1, no. 2, pp. 32-45, 2017.

[7] A. A. Oktaviana, "Hand stencils and boats in the painted rock art of the karst region of Muna Island, Southeast Sulawesi," Archaeol. Sulawesi Curr. Res. Pleistocene to Hist. Period, pp. 6177, 2018.

[8] A. Giddens, Beyond Left and Right: Tarian Ideologi Alternatif di Atas Pusara Sosialisme dan Kapitalisme. Semarang: Balai Penelitian dan Pengembangan Agama Semarang, 2003.

[9] J. Bruck and M. Goodman, Making places in the prehistoric world Making places in the prehistoric world: themes in settlement archaeology. London: University College London Press, 1999.

[10] T. Setiawan et al., Kemaritiman Nusantara. Jakarta: Yayasan Pustaka Obor Indonesia, 2017. 